\title{
Climate Change and Arctic Sustainable Development: Scientific, Social, Cultural and Educational Challenges
}

UNESCO (2009) UNESCO Publishing, Paris. 376 pages.

This publication is unbelievable, and naturalists working "on the ground" know about it. The failure of big and UN governments about Arctic and Climate issues manifests itself here in writing, once again and across many of the covered and diverse topics. Despite some well-meant voices and chapters, most of the writings of this style and by governmental representatives will stand out as a monument in time in regards to "talking big but doing (and achieving) virtually nothing" and for curbing Arctic climate change and global decay. The presented Conservation of Arctic Flora and Fauna (CAFF) program makes for one of many examples. "Today their aim is to conquer, exploit and colonise", this is what the UNESCO Goodwill Ambassador for Arctic Polar Issues has to say about the nations that are busy in the Arctic. Here we see what contributes to the global climate disorder. What has mankind really learned and improved upon?

This book keeps communicating "challenges", but fails to solve them, e.g. by promoting a global financial reform, big institutional changes and through a new (better) form of governance and society. Who should not strive for such a change in times of global crisis?

By now, virtually everybody can see worldwide that Sustainable Development eventually has failed, and that it is very harmful. We have reached the end of another era and its ideology, again; and nature paid the bill once more. This is widely published in the scientific literature and elsewhere, and it can be seen already for decades with Climate Change, as well as in the myriads of habitat and species loss problems. This book has much in stock for naturalists in Canada and elsewhere. Impacts of 'Canadisation' are presented. However, most of our major governmental institutions still keep promoting their disastrous concepts of 'green development' and modernisation, but meanwhile destroying, at full steam, the earth, its biodiversity, habitat and people. This can hardly be called noble and royal. Alone the Foreword section of this book and written by various dignities ("HSH Prince Albert II of Monaco also attended the closing session") makes you already wonder about the environmental mind of our royal families (e.g. Monaco, Denmark, UK, Holland, Sweden and Norway; many are the heads of major oil-run nations and of their industries) and of many world leaders. The Nobel prize is still rooted in such a mind set.

Each of the nine book chapters cover three to six topics (with appendices 4 to 18 brief pages) and by many different authors. A wide variety of Arctic topics is discussed: Ice, Oceans and Atmosphere; Biodiversity and Ecosystem Services; Community-Level Impacts and Adaptation; Health and Well-Being; Economic Development and Social Transformations; Education; Ethics, Responsibility and Sustainability; Monitoring Systems. All Arctic nations and many stakeholders are represented, including many indigenous voices and cultural entities (It is notable here that the U.S. has no Ministry of Culture). Many of the color illustrations, some tables and the literature references (done for each chapter) are informative and can serve as a lasting reference to the readership on political, statistical and Arctic details.

I would like to present here the Greenland chapter in order to exemplify my critique (the book is full of many other examples that fall flat in real world sustainability, such as the Arctic Wetland one and its adaptive management suggestion authored by large NGOs): The climate change disaster is already well-known for these countries; but further, relatively small nations and without any military power and relevant budgets like Greenland (or Iceland for instance) can easily get bought out by the corporate industry and by wealthy nations. Just another social engineering experiment is there in the making: But this time it is run by the corporate industry and covered up by the 'free world'. The chapter authors and editors simply forgot here to consider and to report on all the victims of climate change and of an ideological regime which just favours schemes of resource extraction and money first. Balanced and fair approaches (e.g., at least a 50:50 deal, or much better) seem not to exist (Greenland just gets a $25 \%$ deal for its people). Alone seven more (!) mines are expected to operate in Greenland soon, oil is to be delivered, and the Arctic Shipping Lane comes handy to provide and transport supplies and resources (not to mention all the arctic air traffic; a topic that is not addressed at all in this book). And as if Greenland is not already widely over-harvested and overused enough, e.g. in regards to browsed vegetation, fisheries and seabirds (similar details can be reported for adja- 
cent Iceland also and where $7 \%$ of Atlantic Puffins are yearly harvested and now have problems to even raise any chicks). The promotion of one-sided economic growth schemes does not fight poverty, it simply makes it worse. The Persistent Organic Pollutant (POP) contamination now makes for a great but sad example, and where the supplied European-style food does not provide a good and healthy balance to Greenlanders, whereas the original subsistence food items (but which are now contaminated) are toxic and contribute to cases of diabetes, sudden cardiac death and psychiatric disturbances. That's how climate change starts to look like in real life.

While this book and its impact unfolds, any naturalist can witness here just another genocide in the making. Once more, and same as in Africa (e.g., Hutu and Tootsie conflict, or Sudan and Liberia for decades), or with many other indigenous populations, UNESCO does nothing against it really and huge human losses and sufferings occur. The powerless pay our bills. The presented law suits against Exxon Mobil by the tiny Alaskan village of Kivalina regarding the sea level rise and the disappearance of their home island make that case clearly (villages like Shishmaref and many others have similar issues to fight).

And where is the church from the western world (which otherwise has a strong grip on the UN) and acclaimed gate keeper of humanity (their missionary wrong-doings are covered in some chapters, and so is the colonial history of the Arctic)? The petition lead by Inuit leader and Nobel Peace Prize nominee S. Watt-Cloutier about an urgent "relief from human rights violations resulting from the impacts of global warming and climate change caused by acts and omissions of the United States" clearly show the culprits. The Male Declaration on the Human Dimensions of Climate Change calls for similar action.

But Achim Steiner, Executive Director of UNEP and a known hardcore, long-term promoter of sustainable development from the west, still states in the Foreword of this book boldly: "If you look at climate change in the context of the Arctic you are witnessing humanity's capacity for irrationality at its zenith". But then he kindly missed his own history and UNEP's track-record, and the fact that it is not humanity, but a pseudo-democracy and where the people have not much to say or to decide. Instead, in a sustainable world that would be truly based on scientific facts (but not on purely political administrations), UNEP and its leaders, its funders and business concept would be among the first to go.

On the good side, this book of 356 very well layedout pages, promotes open access and data sharing, and thus transparency of science, governments (funding) and decision-making. It can be seen as a countermeasure to global corruption. However, many of the book contributors are not supporting and enforcing this great scheme in full, e.g., Norway, U.S. National Science
Foundation (NSF), Canada and Russia (The International Polar Year IPY only has a $40 \%$ compliance rate of its data policy). And due to the digital divide (a subject hardly addressed in this book), many of the small countries do not even have the capacity and skill to participate in such endeavour. Cloud computing might provide help (but is not covered in this book).

Besides not considering even the basics of ecological economics or a strict $40 \%$ protection scheme, this book also left out the oil \& gas, and mining industry voices (likely they just prefer to stay quite?). But as an improvement to previous Arctic publications elsewhere, the "Political tensions over sovereignty of the Arctic Ocean" are shown as a real problem and the notion of an 'Arctic Treaty' (similar to the Antarctic Treaty) is at least discussed. Environmental ethics made it into several chapters also.

However, despite being an international UNESCO publication, this book fails also on the inclusion of African, Brazilian, Indian, Korean and Chinese voices (no chapters are devoted to them or provided by them; even views from Poland, Belgium, France and UK are missing).

Our last hope then is the Annex: International Expert Meeting 'Report and Recommendations' (based on the Monaco meeting and leading to this book and 67 recommendations). Well, the urgency of the Arctic problem got expressed, knowledge gaps outlined, and recommendations were made (many of which most governmental participants themselves frequently violate or do not follow even) and which follow the major schemes of the book chapters (Education, communication and outreach; Cultural heritage; Well-being and health; Economic development and resource management; Arctic governance; Establishing, sustaining and strengthening research monitoring systems; Information access and data sharing; Policy and decision support). And so goes the Arctic theatre and with the UN governance.

When it comes to the Circumpolar Arctic, to Climate Change and Sustainable Development, institutions and entities like the Arctic Council, CAFF, the Circumpolar Biodiversity Monitoring Program (CBMP), IUCN, The World Bank, WWF, EU-DAMOCLES and UN all widely failed their basic mandates. They are not proactive, have 'no teeth', no honest performance evaluation, and provided poor leadership thus far resulting in a global environmental crisis which global humanity has never witnessed before. A link with human suffering and loss of life can easily be made worldwide, and with 7 billion people and rising. Therefore, the assigned powers should be withdrawn from these institutions and for a REAL NEW Green Deal to come. This is because, and as every naturalist knows: Nature is our only master.

FALK HuetTManN

Institute of Arctic Biology, Biology and Wildlife Department, University of Alaska-Fairbanks 99775 USA 